\title{
The relevance of Reformed perspectives on demonology for Africa
}

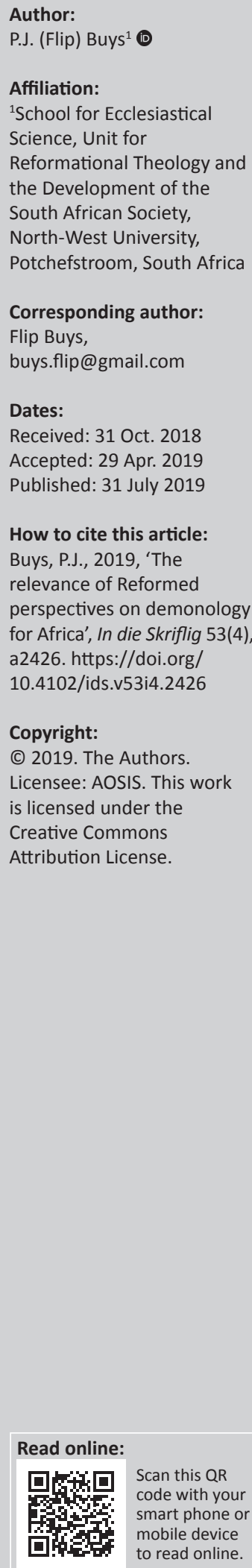

In the debates about lacunas in Western theological education and the need to decolonise Reformed theological education in South Africa, the necessity of understanding demonology has been pointed out as an important area for more research and contextualisation by several researchers. Witchcraft still causes major social problems in South Africa and Africa. On the other hand, there are Reformed theologians in South Africa who expressed opinions and even Reformed denominations that have made synodical decisions that the Devil does not exist as a person and that the existence of demons are myths. Therefore, it is necessary to reconsider the subject of demonology that deals with Satan and his fallen angels from the perspective of traditional Reformed systematic theology and hermeneutics. This article wants to point out that a Reformed hermeneutical study and interpretation of relevant biblical perspectives may enrich the lives of Christians and bring some balance between current extremes in the understanding and application of biblical data on demonology.

Keywords: Demonology; Witchcraft; Satan; Devil; Occult; Demonic Influences; Spiritual warfare; Strategic level spiritual warfare.

\section{Introduction}

This article is partly based on an autoethnographic qualitative research methodology. According to Ellis and Bochner (2000:733), autoethnography is a way to understand a certain culture or a group of people through the eyes and perspective of a researcher who is personally involved with the objects of the research. My personal experience, observations and reflections over a period of 40 years of cross-cultural gospel ministry in South Africa and several other African countries contributed to the insights presented in this article. Personal pastoral interaction with many suffering people, church leaders and theologians who will be referred to in the article, underscore similar findings of other authors also referred to in the article.

The words of C.S. Lewis in the introduction to his classic The screwtape letters (1942) are very relevant for South Africa and Africa:

There are two equal and opposite errors into which our race can fall about the devils. One is to disbelieve in their existence. The other is to believe, and to feel an excessive and unhealthy interest in them. They themselves are equally pleased by both errors and hail a materialist or a magician with the same delight. (p. 3)

This timeless caution is particularly true when we follow the history, literature and theological debates on Satan and demons and critically weigh contemporary missions and ministry practices (Buys 2015), and clothe ourselves with compassion, kindness, humility, gentleness and patience (Col 3:15 - NIV) in the midst of intense suffering and deep pastoral needs of people.

In his thorough treatment of the subject of demonology, Leahy (1990:7) bemoans the fact that there is much vagueness and, at times, error in the Protestant ministries when Satan and the demons are mentioned. According to him, nothing of any importance has been written on the subject from a Reformed standpoint since John L. Nevius, a Presbyterian missionary in China, wrote his Demon possession and allied themes in 1894.

What Manala (2004) wrote about the relevance of the theology and ministry of the Hervormde Kerk in Suidelike Afrika is also applicable to other types of Reformed churches in Africa.

... the service of the Hervormde Kerk in Suidelike Afrika to black African Christians is not relevant because it is founded on a theology influenced by western thought and philosophy. (p. 1504) 
Van Wyk (2004) from the Hervormde Kerk, also pleads for more theological consideration of witchcraft, when he wrote:

I am therefore convinced that the development of theology in Africa will also free this continent from this vicious cycle of fear and murder. When people develop a new understanding of reality and realise that they could handle the complexities of this world in a different, more effective way - then they will also act differently, speak differently and live differently. (p. 1224)

In an in-depth qualitative research article, Janse van Rensburg (2010) states about the Dutch Reformed Church in South Africa:

While Vergeer (2002:372) shows how a variety of synods of the Dutch Reformed Church responded negatively toward a ministry of deliverance, Theron (2001:196) is of the opinion that such resistance is beginning to disappear. He refers to 'some decisions of the different Dutch Reformed Church Synods [that] seemed to be more open to the possibility that this ministry holds'. (p. 680)

In a missiological research study on healing ministry among the Zulu speaking people troubled by evil spirits, Sietse Veenstra (2003) explained how the Reformed churches (nickname: 'Doppers') are quite open to do more intensive study on demonology and several theologians called for the equipping of pastors to do relevant pastoral ministry in this regard. He also pointed out how relevant an in-depth knowledge of witchcraft practices is for cross-cultural ministry in KwaZulu Natal (cf. also Vergeer 2002).

Although the main task and desire of the Christian is to grow in amazement and wonder of the surpassing worth of knowing Christ Jesus as Lord (Php 3:8), it is part of Paul's instruction that Christians must put on the whole armour of God so that they may be able to stand against the schemes of the Devil (Eph 6:11 - ESV). Geisler (2016) points out that 'Of the twenty-nine references to Satan in the Gospels, Jesus made twenty-five of them.'

Thus, the study of Satan and demons is a major facet of God's revelation that provides knowledge, insight and discernment about Satan's character, purposes and spiritual wickedness. That may enable Christians to withstand in the evil day and, having done all, to stand firm (Eph 6:13).

The 17th century Puritan, Tomas Brookes (1984) formulated as follows:

Christ, the Scripture, our own hearts, and Satan's devices, are the four prime things that should be first and most studied and searched. If any cast off the study of these, they cannot be safe here, nor happy hereafter. It is my work as a Christian, but much more as I am a watchman, to do my best to discover the fullness of Christ, the emptiness of the creature, and the snares of the great deceiver. (p. 10)

The development of secularism in the Western world elevated the secular to the point where it is believed that nothing exists beyond that which can be seen and measured. Leahy (1990:132) quotes several 'liberal' theologians who discount the biblical account of demonic activity. In their view, angels, whether fallen or unfallen, including the Devil, belong to the realm of myth, and reflect an outside and pagan influence on the writers of Scripture. In his dissertation, accepted by the Free University of Amsterdam under supervision of Dr. A. van de Beek, Dr. L.F. de Graaff (2004) defended the opinion that angels disappeared to a growing extent from Western churches and theology.

The worldview that there is nothing transcendent to which the secular is accountable, led to many people being ignorant of the nature and schemes of Satan and therefore they become sitting ducks for his attacks (Sproul 2011:30). ${ }^{1}$

Some on the other hand go way beyond the teaching of Scripture and find a demon behind every problem they face as described by Watkins (1990):

My mom's completely flipped out. I mean, she sees demons everywhere. Just this morning the car died on the way to school. She got out, pounded on the hood, and yelled, 'In the name of Jesus, I command the foul spirits of engine stalling to come OUT!' (n.p.)

In his sincere pastoral concern for young Christians, Paul wrote that we should not be outwitted by Satan because of ignorance of his strategies (2 Co 2:11). Paul also warns that Satan disguises himself as an angel of light (2 Co 11:14, 15).

Merrill Unger (1991:20) says that in Early Church history, writers such as Justyn Martyr, Lactantius and Augustine dealt with this subject, but 'For nearly a millennium and a half, for some strange reason, the true Biblical doctrine of demons was hardly spoken of.' By the 19th century, he (Unger 1994:viii) says: '.. the whole subject was sneered at by many as a superstitious idea which we had well get rid of, or was quickly passed over in theological circles'.

\section{Problem statement}

The historical developments, the realities of struggles with witchcraft in Africa and the ignorance of young people who grew up in Reformed churches, raises the question: What answers may Reformed perspectives, based on traditional Reformed hermeneutics, offer for a balanced pastoral approach in dealing with demonology $?^{2}$

1.I often counselled young people and university students who grew up in Reformed cope with struggles of real-life problems such as the processing grief, unresolved conflicts and bitterness, got pulled into spiritism, the use of drugs, satanic rituals and eventually became members of secret satanic covens. In my cross-cultura ministry, I experienced isizulu and isiNdebele people who were izangoma or experiencing the 'call' to become isangomas radiating bizarre behaviour, shouting and screaming when the name of Jesus Christ was mentioned in teaching or in personal pastoral counselling sessions.

2.One of the main goals of In die Skriflig is to promote Reformational theology. Therefore, this article is written from the perspectives of Reformed hermeneutics that accepts the Bible as the authoritative Word of God. I associate myself with the views of Jordaan, Janse van Rensburg and Breed (2011:225-258) on the character of Reformed hermeneutics. Compare also Vanhoozer's defence (1998:210) of 'the of Reformed hermeneutics. Compare also Vanhoozer's defence (1998:210) of 'the possibility, in the vale of the shadow of Derrida, that readers can legitimately and responsibly attain literary knowledge of the Bible ... that there is a meaning in the text, that it can be known, and that readers should strive to do so'. Also compare how Vanhoozer (2005) convincingly points out how the bedrock of hermen criteria are grounded in the canon itself, the patterns of God's story, the revelation of God's character through the story and, most particularly, in the culmination of God's theo-drama in Jesus Christ. 


\section{Brief historical overview and developments of current trends}

In order to exercise the same pastoral concern for the people, God has entrusted to our care pastors and theologians who need to know the historical developments and present-day trends of thinking concerning Satan and demons.

Christian thought about Satan remained fairly consistent until the 17th and 18th centuries.

From about 1850, the ushering in of the Age of Enlightenment (Rath 1999-2003:96) started as a consequence of rationalism industrialisation and the rise of modern science. Human reason and intellectual proof was advocated as the primary source for legitimacy and authority. Millions in the Western world were influenced to embrace an overoptimistic view of the so-called 'scientific approach'.

Religious persecutions and wars also pushed people toward scepticism about religion. Darwin, Marx, Nietzsche and Freud helped to create a worldview according to which supernatural powers could not interrupt the natural realms of cause and effect. Since then, a growing number have dismissed the Devil as a figment of human imagination or as the 'psychology of the ancients' no longer relevant in efforts to explain evil today. In the radical form, expressed by Nietzsche: God is dead, Satan is dead (Hinson 1992:472).

A rapidly growing number of theological and philosophical scholars developed a method of interpreting Scriptures in which they demythologise and allegorise the biblical records on evil spirits. Rudolph Bultmann (1958:17) - soon followed by many others - made an attempt to make the message of the Bible fit a European enlightenment paradigm that, he reckoned, did not share the worldview of the 1st-century Mediterranean people. He argued that the biblical language on the spirit world and the miraculous was merely a human way of speaking about God and not describing what was happening in actuality.

This kind of theologising, marginalised the Devil more and more to the periphery in Christian thinking and stimulated a worldview with a flaw of the excluded middle (Hiebert 1982; Moyo 1994:59-60).

The growing movement of liberal theology in some mainline churches in South Africa is leading to a total denial of the existence of Satan and demons. Janse van Rensburg, a theologian of the Dutch Reformed Church, highlighted this in his book with the title: The occult debate (1999). He made it clear that epistemological views on occultism within the Reformed tradition have drastically parted their ways in South Africa. During the General Synod of the Dutch Reformed Church in 2007, a report on a ministry of deliverance denied the existence of the Devil and claimed that it would be unscientific to embark on an empirical research in this regard (Dutch Reformed Church 2007:18-30).
Kirkpatrick (2007:19) expressed a view at the seminary of the Dutch Reformed Church in Pretoria that any ministry of deliverance or theological discussion on demon possession and other forms of demonic influences are to be perceived as nonsensical (cf. also Janse van Rensburg 2010:679-697).

Theologians of this camp speak about the Devil with a tongue-in-the-cheek attitude. They refuse to believe in the existence of the Devil as a person and ridicule the whole idea. This denial of Satan's real personal existence usually takes the form of defining the idea of Satan as the mythical personification of evil, but not actually as a being who really exists. Schleiermacher (as quoted by Viljoen \& Floor 2006) wrote:

Christ and the apostles might have said these things about angels without having had any real conviction of the existence of such beings ... as, for example, we might talk of ghosts and fairies. (p. 40; cf. also Van Aarde 1987:13)

Schleiermacher expresses the opinion that believing in the Devil is merely a form of escapism. However, people who have done research on the field of occultism and people who are involved in a ministry of deliverance would simply not accept such an assumption (cf. De Beer \& Van den Berg 2007:24-30; Ouweneel 1978).

Another development is that of Hendrikus Berkhof (1952:25) who, in following Karl Barth, argued that Paul's language concerning the powers in Ephesians and elsewhere was an attempt by the 1st-century person to describe real social, economic, psychological and political structures that affected their everyday lives. He also denies the existence of a personal being called the Devil, insisting that it is a 'collective symbolization of evil' and 'the collective of weight of human fallenness'. Rather than personal evil spirits, these forces are the inner or spiritual principles of an institution or nation the culture, ethos and gestalt that affect how things are run.

Throughout history, overtly evil socio-political systems such as the idolatry of the Roman Caesars, the anti-Semitism of Hitler's Nazism, the evil of human slavery, the atheism of the Communists, the dehumanisation of Apartheid, the wickedness of the ethnic cleansing in parts of Africa, racism and terrorism of all forms, and the greed of capitalism have all demonstrated the extent to which the evil powers can influence world systems and seek to thwart the blessings of humanity.

In covert forms, evil powers continue to influence humanity in the addiction of people in the drugs culture, in postmodern hedonism, the explosion of the pornographic industry, the disdain for the sanctity of human life, and the tyranny of secularism which denies people their true liberty to serve God. In personal pastoral counselling experience, I observed that young people who got involved with satanic covens all became hooked on drugs, pornography and eventually violent bizarre and troubled behaviour. 
Through the tragic history of Western civilisation since 1914, the onset of the First World War, the Devil, as a person who is evil, has also made a comeback. The unimaginable evilness of evil in the 20th century convinced many people to believe in the Devil again. Christopher Nugent (1989:30), a historian at the University of Kentucky, has labelled the period beginning with the Third Reich 'The kingdom of night: A century of Satan'. He points out how the Western world has begun to lose its faith not in religion, but in science and the autonomous human reason. Secularism has produced two devastating world wars; industrialisation has created a series of mounting ecological disasters, and the West has begun to lose its faith not in religion, but in science and the autonomous human reason. The moral crisis of our time, says David Harvey (1990:41), is a crisis of Enlightenment thought. The 'inevitable' triumph of atheistic secularism did not happen. At a conference of the Europe branch of World Reformed Fellowship at Utrecht in October 2007, Peter Jones (2007; cf. also Jones 1979), in his paper with the title 'Paganism, the step-child of secularism', pointed out how wide and deep issues like witchcraft, alternative healing and occultism is spreading in Western Europe. ${ }^{3}$ He referred to Andre Malraux who, in the middle of the 20th century at the high point of the achievements of secularism, predicted that the 21st century would be religious. Jones also agreed with postmodern deconstructionist, Mark C. Taylor, professor at Williams College, who observed that the 21st century would be dominated by religion in ways that were inconceivable just a few years ago. 'The irony is delicious', says theologian Don Carson (1996:100), 'the modernity which has arrogantly insisted that human reason is the final arbiter of truth has spawned a stepchild that has arisen to slay it' (cf. also Lovelace 1976:65-90).

One example is that, in postmodern New Age circles, one finds an obsession with and many speculations about angels. With regard to angels - which overlap with the doctrine of demonology - Noll (1998:11) makes the following remark: 'To theologize about angels is a most dubious undertaking in our day. But to ignore the subject of angels is to miss one of the comeback stories of the century.'

In postmodern circles, the view is propagated that one should seek to communicate with angels in light of a belief that every human being has a guardian angel. Such a guiding spirit is regarded as more approachable than God and therefore you should pray to your guardian angel. They also believe in healing angels and comforting angels (cf. Joubert 1997:53). The New Age Movement also encourages people to discover their psychic abilities. Interest in spiritism, witchcraft and clairvoyance (predicting the future) has drastically grown among all layers of society. Celebrities, receiving entertainment awards, publicly credit their 'spirit guides' for their success. The contemporary question for many today is

\footnotetext{
3.At the end of the session of Peter Jones, I asked Dr. Victor Cole, the academic dean of the NEGST (Nairsion Evangelical Graduate School of Theolog) who was sitting of the NEGS 'Nairobi Evangelical Graduate School of Theology) who was sitting next to me. 'So, what can we, coming from Africa, now say to the Western world after this paper of Peter Jones?' His tongue-in-the-cheek answer was: 'Welcome back.'
}

not the medieval query about how many angels can dance on the head of a pin, but how one may contact, converse with and 'hug' one's guardian angel.

African people treat demonology with great respect. Their worldview has given much space to these phenomena. Therefore, when the West meets the non-West, there has previously been difficulty in reconciling differences. Demon activity is very real for African people as being pointed out by several scholars from South Africa and Africa (Kathide 2007; Kato 1975; Manala 2004; Mbiti 1975; Nyirongo 1997; Turaki 1999).

In South Africa, the HIV pandemic has led to a new explosion of witchcraft, steeped in occult rituals and practices, and witchcraft medications (cf. sociological research of Ashforth 2001). People are so desperate to find healing from HIV and AIDS that witchdoctors and wizards have grabbed the market to advertise potions and rituals for healing. Research projects have revealed that muti shops around Soweto have become a major economic endeavour (Gossmann 2012). I have personally been at the sickbeds and deathbeds of terminally ill AIDS patients who were mixing sangoma muti [witchdoctor or traditional healer medications] ${ }^{4}$ with antiretroviral (ARV) medication that cost them around R2000 - more than the ARV medication - with the reasoning that it will call on ancestral spirits to rescue them from the 'bad luck' of demonic spirits.

In significant parts of African Christian circles, there is no difficulty at all in accepting the existence and reality of the influence of evil spirits. Confusion in this regard in Nigeria and the Congo is so bad that Pentecostal pastors demand large amounts of money to exorcise evil spirits from vulnerable children to assist their parents or caregivers to be liberated from all sorts of illnesses which are caused according to their beliefs - by children who are possessed by a demon (cf. Ellison 2018).

Any first-time visitor to an African initiated church service in any of the cities of West, Central and Southern Africa will be most impressed by the frequent reference to the Devil and his demons. I observed prayers for exorcising demons binding Satan and delivering the oppressed in several church services. Not only are the worshippers conscious of the battle against evil spirits, but many church members and preachers specialise as 'prayer warriors' who wage spiritual warfare against evil spirits.

A number of African scholars have argued that the situational context of Africa demands a contextualisation that regards specific teachings as special cases for Africans. As eloquently put by Emmanuel Asante (2001:358), 'Understood as deliverance not only from one's sinful selfhood but also from evil forces, salvation must address the concepts of evil and sin in the African context.' It makes no sense to the African to

4.In Southern African society, the Sangoma acts as a therapist for issues of health, luck, love, dream interpretation, sexual problems or business ventures (Chic African Culture 2015). 
deny the presence of evil powers or to have a Saviour who could not provide a complete and decisive victory over such powers.

\section{Asante (2001) further explains:}

The African reality demands a Saviour who has the power not only to deliver the believer from evil powers but also to transform the lives of the bewitched and the dehumanized, enabling them to live actively in the community. (p. 358)

The concept of generational curses is an endemic worldview in parts of Africa (Makashinyi 2019). In Christian circles, it is based on an invalid understanding of Old Testament phrases such as 'visiting the iniquity of the fathers unto the third and fourth generations of those who hate God' (Ex 20:5; 34:7; Nm 14:18; Dt 5:9). Marilyn Hickey (2000:13) defines it as 'an uncleansed iniquity that increases in strength from generation to generation affecting the members of that family and all who come into relationship with that family'. A failure to emphasise God's sovereign grace and the complete victory of Christ over such generational spirits, only fosters a mentality that paralyses believers.

What Joseph Quayesi-Amakye (2015) states about phenomena in Ghana is typical of many African countries:

In this regard exorcism/deliverance, prayer and prophetic negotiation/rituals become a major practice in many Pentecostal prayer services. Perhaps, such spiritualization helps to show the impingement of the Akan traditional religion on Ghanaian Pentecostal contextualization of the Gospel. Maybe it reveals the extent to which such understanding becomes normativein Ghanaian peripheral Pentecostal theology. (p. 1; cf. also Mbewe 2013 about phenomena in Zambia)

The same teachings about deliverance became very popular in the US through Frank Peretti's two spiritual warfare novels, This present darkness (1988) and Piercing the darkness (1989), which captivated so many readers that more than 3.5 million copies have been sold.

In riveting storytelling, Peretti manages to excite imaginations on how evil spirits may operate to influence the daily happenings in villages and towns across the USA and in the world at large.

Although merely novels, Peretti's creative accounts have quickly influenced a theological worldview in some evangelical circles that they now see demons underneath almost every mug in the kitchen or table in the study and behind every bush. Without intending to do so, he has facilitated a systemisation of the evil powers in the world far beyond what the Bible teaches (see Guelich 1991:33-64 for analysis of Peretti).

Somewhat contemporaneous with the publication of Peretti's works, Peter Wagner (Donald A. McGavran Professor of Church Growth at Fuller Theological Seminary) became a leader of a growing spiritual warfare movement that promotes direct power encounters with demons and territorial spirits as a vital aspect of effective missions. Wagner (1993:200) says: 'The real battle for both world evangelisation and social justice is a spiritual battle and our principal weapon of spiritual warfare is prayer.'

At the International Lausanne II Conference in Manila in 1989, the spiritual warfare movement gained an official hearing from evangelical leaders when a 'Spiritual Warfare Track' was established under the direction of Charles Kraft. The establishment of the AD 2000 United Prayer Track and the Spiritual Warfare Network under Wagner's leadership further strengthened the movement. Since then, conferences on spiritual warfare have been held throughout the US. This fixation on our supernatural enemy has given rise to a phenomenon of books on 'spiritual warfare': by last count, over 400 books have been published on this subject in the 1990s!

Clinton Arnold (1992) challenges us to 'get the upper hand on [demons] before they get it on us'. He evaluates such aspects of contemporary spiritual warfare as 'demolishing strongholds', 'demon possession', 'binding the strong man', 'strategic level spiritual warfare' (SLSW), 'warfare prayer', 'territorial spirits', 'spiritual mapping', 'identificational repentance', the 'genealogical transmission of demons', 'deliverance ministries', 'power encounters' versus 'truth encounters', et cetera. Some of the claims made by spiritual warfare writers are alarming.

This approach fits well with traditional African worldview and is embraced in parts of Africa. With regard to the concept of territorial spirits, Opoku Onyinah (2004:337) points out that it is 'the notion that the demons assume a hierarchy with powers of greater and lesser ranks, and having specific geographical assignments'. Derived from Daniel 10, the teaching emphasises that territorial spirits wield their influence over particular geographical regions, tribes, people groups, neighbourhoods and other significant social networks. The result of their influence is to change the course of the social, economic and political situations in the world.

Systematising this teaching further, some interpreters on the continent of Africa have speculated that these demonic powers have specific names that are required to be known if spiritual warfare is to be successful. In yet a further interpretation, the concepts of ancestral spirits are merged with territorial spirits to produce a doctrine that requires nations to exorcise the demons of economic mismanagement and corruption before the African continent may begin to prosper (Asamoah-Gyadu 2004:389-406).

All these extremes create the necessity for a comprehensive understanding of a biblical and valid hermeneutically based perspective on demonology.

As David Powlison says: 'A great deal of fiction, superstition, fantasy, nonsense, nuttiness, and downright heresy flourishes in the church under the guise of "spiritual warfare" in our time' (quoted by Taylor 2012). 
It often distracts the attention from the real warfare which we need to wage and mislead Christians to bypass the most important issues for the church and God's kingdom.

\section{The authority of Scripture and hermeneutical practice}

In considering the publications about Satan, demons and angels, it is apparent that paths within theological approaches and church practices around demonology separate on opinions about the authority of Scripture and valid hermeneutics.

It seems that those who deny the ontological existence of Satan and demons, and those who become obsessed with the Devil and demons have one thing in common. They do not take the authority of Scriptures seriously and, as a result, they apply a hermeneutical approach in their interpretation of passages and its applications on phenomena that, in fact, denies the unity of Scripture and the basic Reformational rule that Bible passages should be understood within their context, that the goal or scopus of a text should determine the meaning of a passage, and doctrine should be formulated through comparing various passages that deals with the same truths (Sacra Scriptura sui ipsius interpres). As Berkouwer (1975) formulates:

Nowhere was the relationship between authority and interpretation so clearly expressed as in the Reformation confession of Scripture, which, based on sola Scriptura, offered a perspective on the real relationship between authority and interpretation, and expressed it in its hermeneutical rule: Sacra Scriptura sui ipsius interpres [Sacred Scripture is its own interpreter]. (p. 127)

Heyns (1978) formulates the same principle as follows:

\begin{abstract}
Die sleutel vir die verstaan van hierdie kernprobleem ten opsigte van die ontstaan van die Skrif, en tewens ook vir die verstaan van die ganse Skrif na sy vorm en boodskap, mag nie van buiteBybelse oorsprong wees nie. Ons mag nie met 'n sleutel in ons hand na die Bybel gaan om so sy diepste geheime te ontsluit nie. Vir die verstaan van die Bybel gee die Bybel self aan ons die sleutel. Die diepste bedoeling van die bekende Reformatoriese slagspreuk sacra scriptura sui ipsius interpres was dan ook nie net dat elke Skrifgedeelte in die lig van die geheel verklaar moet word nie, maar dat die Skrif self moet sê wie, wat en waarvandaan hy is. Die Bybel en niks anders nie, is die norm en die bron vir die verstaan van die Bybel. Insig in die openbaring is alleen moontlik in die lig van die openbaring. (bl. 18)
\end{abstract}

This inevitably leads to the epistemological question of how one comes to the truth. Crucial questions that should be asked are the following:

1. Is the use of anecdotes sufficient to establish a doctrine and justify new practices? Davis (2007:97) refers to research of Priest, Campbell and Mullen on 'Missiological Syncretism', who seriously question what they call the 'epistemological underpinnings of these doctrines'. Aside from the lack of Scripture support, they fault modern-day SLSW leaders for basing these 'new' doctrines on:
- interviews with demons resident in demonised persons;

- information about demons gathered from practitioners of occult and animistic folk religions (and assuming it corresponds to reality);

- frequently told and retold anecdotes and missionary testimonies;

- pragmatism: the SLSW method 'works';

- their own 'spiritual' discernment (they call it 'inner Geiger counters');

- personal revelations from God (special 'words of knowledge').

2. Should we accept information from the spirit world and claim to receive accurate information from demons? Charles Kraft (1995:98) defends himself and Peter Wagner, relying on animist beliefs in dealing with the spirit world and suggests that animists are not as ignorant as some may think, and possess reliable knowledge concerning principles that govern the spirit world.

3. What is the relation between the authority of Scripture and guidance of the Holy Spirit? Wagner (1996:20) claims that God told him to take leadership in the area of territorial spirits and claims to have apostolic authority and a divine appointment to reshape Christianity, which is primarily based on extra-biblical revelation. He and Kraft claim that they have special guidance from the Holy Spirit, as the third wave of the Holy Spirit revival has been ushered in. Yet, even other charismatic theologians fiercely reject this doctrine.

Scott Moreau (as quoted by Van der Meer 2008:28) rightly states: 'As Evangelicals we can never allow personal narratives to replace the investigative methods of history, the social sciences and theology which have stood the test of time.'

Reformed Christians have always primarily put their faith in the Lord who has revealed himself in his Word. It is his Word that has the authority in our lives. This means that our personal experience is never the authority upon which we base our beliefs on Satan and demons.

The words of the Holy Spirit in Scriptures teach, rebuke, correct and train Christians. Personal experiences or the experiences of anyone else, no matter how wise or learned they may appear, may never become primary sources of faith.

\section{Biblical teaching on Satan and demons}

\section{The existence or reality of Satan}

Satan is not just an evil, impersonal influence, but a very real person - a fallen angel with supernatural powers. ${ }^{5}$

\section{The nature of Satan}

Satan is a fallen angel. Therefore, all that is true of angels in general is true of Satan and his fallen angels (demons).

5.This section of the article summarises insights of De Bont (1948) and Emanuel (2014). 


\section{He is a creature}

Like all angels, Satan is a creature, created by Christ, the Creator of all things as it is written in Colossians 1:15, 16:

He [Christ] is the image of the invisible God, the firstborn of all creation. For by him all things were created, in heaven and on earth, visible and invisible, whether thrones or dominions or rulers or authorities - all things were created through him and for him (cf. also Jn 1:1; Ps 148:1-5).

Dunn (1996:90) rightly states that in the final clause of the verse, if 'everything ( $\tau \grave{\alpha} \pi \alpha \dot{v} \tau \tau)$ was created and exists [perfect tense] through him and for him, that presumably also distances Christ from creation as creation's means and end'.

\section{He is a spirit being}

Hebrews 1:14 describes angels as spirits. Demons are called unclean spirits (Mt 8:16; 12:45; Lk 7:21; 8:2; 11:26; Ac 19:12; Rv 16:14). The fact that we are told that: we do not wrestle with flesh and blood, but against the principalities, against the powers, against the world rulers of this present darkness, against the spiritual hosts of wickedness in heavenly places (Eph 6:12), also suggest that Satan and his demons are spirit beings. Finally, the fact that Paul describes them as invisible, also shows that they are spirit beings (Col 1:16).

\section{Satan has limitations}

Although extremely powerful, Satan is not omnipotent, omniscient or omnipresent. He simply cannot be everywhere at once. However, as the chief of his forces of demons or as the 'prince of the power of the air' (Eph 2:2), he is chief of a vast host of demons who are so numerous as to make Satan's power and presence seem to be practically ubiquitous or everywhere at once (cf. Mk 5:9).

Because of this limitation, many references to Satan or the Devil include his whole kingdom. The person of Satan does not personally tempt each of us, for he simply cannot do that. $\mathrm{He}$ is only able to do so through his influence in world systems and hosts of demons.

\section{Summary of gospel demonology}

Considering all the data in the New Testament demonology, it may briefly be summed up as follows (Oesterley 1906:442):

1. Demons are under a head, Satan; they form a kingdom.

2. They are incorporeal and generally, although not necessarily invisible.

3. They inhabit certain places which they prefer to others.

4. They tend to live in groups.

5. They have names and are sometimes identified with their victims and at other times differentiated from them. They are the cause of mental and physical disease to men, women and children.

6. They can pass in and out of human beings and even animals.

7. More than one can take possession of a human being at the same time.
8. Christ made it one of his chief aims to overthrow this kingdom and set up his own in its place.

9. Christ cast out demons through his own name or by his word.

10. Christ could delegate this power which was regarded as something new.

11. Christ never treats the possessed as wilful sinners which is in strong contrast to his words to the scribes and Pharisees.

12. Only on the rarest occasions does, Christ come into direct contact with the possessed.

13. Christ's divine and human natures are recognised by demons.

14. At Christ's second coming, the members of Satan's kingdom are to be condemned to eternal fire.

\section{The difference between gospel demonology and Jewish beliefs in the times of the New Testament}

It would be most unscientific to ignore the fact that, in spite of many points of similarity and even of essential identity, the demonology of the Gospels offers something sui generis and differs significantly from Jewish beliefs in the times of the New Testament. Oesterley (1906) points the following differences out:

In the one there is nothing eccentric, nothing done for effect, or for self-glorification, there is no casting out of demons for the sake of exhibiting power, there is none of the 'wonder-working' which characterizes other systems; one object, and one only, runs through the whole of the accounts of the casting out of demons, namely, the alleviation of human suffering. To give in any detail the points of difference between the general subject of demonology and Gospel demonology would be impossible here, but, when the great mass of facts has been studied, the contrast between the two can be compared only to the contrast between folly and seriousness. ... It is well also to remember that the advance of Modern Science, especially in the domain of Psychology, has revealed problems whose most important result is to show how extremely little we know about such things as 'secondary personality', the 'subliminal self', 'change of control', etc. etc. - in a word, how hidden still are the secrets of the region of the supersensuous.

... Christ saw in the case of every 'possessed' victim a result of sin, not necessarily through the co-operation of the victims; $\sin$ He saw embodied in 'Satan', who is identified with 'demon' (see above); he was the personilication of the principle of Evil, which was manifested in men in a variety of ways. When Christ 'exorcized' a 'demon', He, by His Divine power, drove the evil out, and at the same time obliterated the visible results of sin. (p. 443)

\section{The work of demons in the lives of non-believers}

Non-believers who are worshipping false gods are in fact worshipping demons. Paul says in 1 Corinthians 10:20: '... what pagans sacrifice they offer to demons and not to God'. 
When God commissioned Paul, he sent him to turn the Gentiles, the unsaved, 'from darkness to light, and from the power of Satan to God' (Ac 26:18).

Not only does Satan hold the unsaved under his reign, but he also blinds the minds of unbelievers so that they cannot see the light of the gospel (2 Cor 4:4).

By worshipping demons, participating in practices of divination, telling fortune or interpreting omens, or being a sorcerer, a charmer, a medium, a necromancer or one who inquires information from the dead, people open themselves up to demonic control. Such things are an abomination to the Lord so that eventually their thoughts, their deeds and their identity more and more become dominated by an alternate personality - by another being (Koch 1986; Ouweneel 1978).

Demonised people are not just hallucinating when they say that they are hearing voices. They are really hearing voices. They are not just manifesting another personality that they invented from trauma to cope with suffering. This is what some people do, but maybe they have rather opened themselves up through lies, temptations, accusations, spiritism, demonism, occultism and addiction to the point where they actually have demons - unclean spirits at work in them and through them to destroy them. Richard Gallagher (2016), a board-certified psychiatrist and a professor of clinical psychiatry at New York Medical College recently stated in an article in Washington Post:

... careful observation of the evidence presented to me in my career has led me to believe that certain extremely uncommon cases can be explained no other way. I believe I've seen the real thing. Assaults upon individuals are classified either as 'demonic possessions' or as the slightly more common but less intense attacks usually called 'oppressions'. A possessed individual may suddenly, in a type of trance, voice statements of astonishing venom and contempt for religion, while understanding and speaking various foreign languages previously unknown to them. The subject might also exhibit enormous strength or even the extraordinarily rare phenomenon of levitation. (n.p.; cf. also Collins 1976:237-239)

Medication can help for some who have a physical condition, but those who are demonised, need Jesus. They also need repentance and truth, and the indwelling presence and power of God the Holy Spirit so that they will be controlled by the power of God and not the power of the enemy.

\section{The attack of demons in the lives of believers}

Demons do not own or possess any Christians. A Christian is God's sole possession. However, Christians can open themselves up to demonic influences. Even though they belong to God, they can participate with Satan as Peter does on one occasion where Jesus had to say to him: 'Get behind me, Satan' (Mt 16:23; Mk 8:33). Satan did not fill and control Peter, but Peter was listening to him, speaking for him, working for him. So Jesus rebuked Satan and ultimately
Peter's work with him. An unbeliever can end up like the demonised man who was totally controlled. Believers can end up like Peter, participating in the enemy's work even though they belong to Jesus.

\section{The devices Satan uses to attack people Pride}

The Bible often makes it clear that pride is not only the reason for Satan's fall, but also the source of all that is demonic.

That is why James specifically refers to pride when he instructs Christians how to resist the Devil.

'God is opposed to the proud, but gives grace to the humble. Submit therefore to God. Resist the devil and he will flee from you' (Jm 4:6-7).

\section{Hanging on to grudges}

In Ephesians 4:27, Paul warns believers against giving Satan a foothold. Bitterness, pride and the lack of self-control during anger give the Devil a half open door through which he attacks. A desire for retaliation is instigated by Satan.

\section{The full armour of God}

The most important fact about Satan that Scripture gives us is that he is a defeated foe. Colossians 2:15 tells us that Jesus Christ disarmed the powers and authorities, and 'made a public spectacle of them, triumphing over them by the Cross'. Satan has lost the big war. He is now engaged in guerrilla warfare against us and we can defeat him in this day-to-day struggle. Paul's instruction to put on the full armour of God is a command.

Christians clearly have the identity (being in Christ), the authority (being seated with Christ) and the mandate to resist Satan and his demons. They do so not based on their own goodness, but because of Christ's finished work on the cross. Because the One who is in us is greater than the one who is in the world (1 Jn 4:4), Christians can successfully stand against demonic schemes. Their weapons in this ongoing struggle include their authority as seated with Christ at the right hand of God, far above every power (Eph 1:15-2:6), the name of Jesus (Phlp 2:10), their spiritual armour (Eph 6:18), prayer (a must in all cases - Mk 9:29), simple resistance (Jm 4:7), forgiveness (Eph 4:26-32), and exhibiting the fruit of the Spirit (G1 5:22-23; Eph 4:22-29; 6:10-18).

I agree with Collins (1976:239), Gallagher (2016) and QuayesiAmakye (2016) that it is necessary to 'demystify' demonic activities. People need to be assured of God's sovereign control over all satanic hordes, including witchcraft. They also need to be taught to know what the Bible says about the Devil and his strategies that thrives on Christians' ignorance of their position in Christ. Pastors must take up their roles as spiritual shepherds of the church so that unwarranted 
prophetic excesses can at least be minimised. In order to help pastors and Christian counsellors to practice proper discernment when they counsel people suffering from demonic possession or warning signs of occultism and witchcraft, they should opt for teamwork including psychological and psychiatric experts as well as prayer support of spiritually mature Christians

Paul notes that, through the church, 'the manifold wisdom of God' will be made known to the principalities and powers. As the church, as the bride of Christ, extends the gospel, the very presence of the church is a declaration of the manifold wisdom of God to these evil powers. John Stott's explanation (as quoted by Asumang 2008:8) of this verse is not just poetic, 'The multi-racial, multi-cultural community is like a beautiful tapestry ... History is the theatre, the world is the stage, and the church members in every land are the actors.'

\section{Conclusion}

The testimony of the Scriptures regarding Satan and demons is clear and cohesive. They are angelic entities who oppose God's sovereign control. They seek to work out their unholy rebellion by influencing people to live in a way contrary to God's expressed intentions. At the same time, they remain under his sovereignty and can be used by him to affect the divine plan. Christians must submit themselves to God and resist the attacks of Satan and his hosts. To do so, they must be aware of the basic truths presented in Scripture concerning not just the ontology of Satan and demons, but their methods, as they attempt to influence people's lives. Once aware, they are to take their stand in Christ and oppose the working of demons, whether personally, corporately or in the structures and systems of society.

\section{Acknowledgement Competing interest}

The author declares that no competing interest exists.

\section{Author contributions}

I declare that I am the sole author of this research article.

\section{Funding}

This research received no specific grant from any funding agency in the public, commercial, or not-for-profit sectors.

\section{Data availability statement}

Data sharing is not applicable to this article as no new data were created or analysed in this study.

\section{Disclaimer}

The views and opinions expressed in this article are those of the author and do not necessarily reflect the official policy or position of any affiliated agency of the authors.

\section{Ethical consideration}

This article followed all ethical standards for carrying out research without direct contact with human or animal subjects.

\section{References}

Arnold, C.E., 1992, Powers of darkness: Principalities and powers in Paul's letters, IVP, Downers Grove, IL.

Asamoah-Gyadu, J.K., 2004, Prosperity and poverty in the Bible: Search for balance, viewed 29 October 2018, from https://www.lausanne.org/content/prosperityand-poverty-in-the-bible-search-for-balance

Asante, E., 2001, 'The gospel in context: An African perspective', Interpretation 55(4), 355-366. https://doi.org/10.1177/002096430005500402

Ashforth, A., 2001, AIDS, Witchcraft, and the problem of power in post-apartheid South Africa, viewed 29 October 2018, from https://www.sss.ias.edu/files/ papers/paperten.pdf.

Asumang, A., 2008, 'Powers of darkness: An evaluation of three hermeneutical approaches to the evil powers in ephesians', Conspectus 5, 1.

Berkhof, H., 1952, Christus en de machten, Callenbach, Nijkerk.

Berkouwer, G.C., 1975, Holy scripture, ed. J.B. Rogers, Eerdmans, Grand Rapids, MI.

Brookes, T., 1984, Precious remedies against Satan's devices, Banner of Truth, Edinburgh.

Bultmann, R., 1958, Jesus Christ and mythology, Scribner, New York.

Buys, P.J., 2015, 'A biblical and Reformed perspective on demonology', viewed 15 April 2019, from http://wrfnet.org/articles/2015/04/wrf-international-director-dr-p-jbuys-presents-biblical-and-reformed-perspective\#.XNKnkEhS_Dc.

Carson, D.A., 1996, The gagging of God: Christianity confronts pluralism, Zondervan, Grand Rapids, MI.

Chic African Culture, 2015, 'African witchdoctors, Sangoma, Nyanga and traditional healers', viewed 15 April 2019, from http://www.theafricangourmet.com/2015/ 03/africa--bones-witchdoctors-sangoma-traditional-healers.html.

Collins, G.R., 1976, 'Psychological observations on demonism', in J.W. Montgomery (ed.), Demon possession: A Medical, Historical and Theological Symposium, pp. 237-251, Bethany Fellowship, Minneapolis, MN, paper presented at the University of Notre Dame under the auspices of the Christian Medical Association, 8-11th January, 1975.

Davis, K.L., 2007, 'Contemporary spiritual warfare and missiology', Journal of Ministry and Theology 11(2), 77-118.

De Beer, M.J. \& Van den Berg, J.-A., 2007, 'Die ondersteuning van okkult gerehabiliteerdes: 'n Pastoraal-teologiese model vir die toerusting van fasiliteerders', Acta Theologica 27(2), 23-43. https://doi.org/10.4314/actat.v27i2. 5498

De Bont, A., 1948, De Satan, Bosch \& Keuning, Baarn.

De Graaff, L.F., 2004, De verdwijning der engelen uit kerk en teologie: engelen. oude voorstellingen en nieuwe ervaringen, Boekencentrum, Zoetermeer.

Dunn, J.D.G., 1996, The epistles to the Colossians and to Philemon: A commentary on the Greek text, Eerdmans, Grand Rapids, MI.

Dutch Reformed Church, 2007, Report of a committee to the general synod, Agenda, pp. $18-30$.

Ellis, C. \& Bochner, A.P., 2000, 'Autoethnography, personal narrative, reflexivity', in N.K. Denzin \& Y.S. Lincoln (eds.), Handbook of qualitative research, 2 nd edn. pp. 629-668, Sage, New Delhi.

Ellison, M., 2018, How Nigeria's fear of child 'witchcraft' ruins young lives. Abandonment, persecution, violence: Childhoods lost as young Nigerians are branded as witches, viewed 20 April 2019, from https://www.aljazeera.com/ indepth/features/nigeria-fear-child-witchcraft-ruins-young-lives-181112 055349338.

Emanuel, D.M., 2014, 'Satan', in D. Mangum, D.R. Brown, R. Klippenstein \& R. Hurst (eds.), Lexham theological wordbook, Lexham Press, Bellingham.

Gallagher, R., 2016, As a psychiatrist, I diagnose mental illness. Also, I help spot demonic possession. How a scientist learned to work with exorcists, viewed 20 April 2019, from https://www.washingtonpost.com/posteverything/wp/2016 107/01/as-a-psychiatrist-i-diagnose-mental-illness-and-sometimes-demonic -possession/?noredirect=on\&utm term $=.8878$ b8980e17.

Geisler, N. L. 2016, The doctrine of angels \& demons, Bastion Books, Kindle Edition. (NGIM Guide to Bible Doctrine, Book 5).

Gossmann, C., 2012, 'I don't believe in magic potions, but my friend used some to turn into a fly': Making sense of traditional healing culture in South Africa, viewed 29
October 2018, from http://www.slate.com/articles/life/dispatches/2012/01/ October 2018, from http://www.slate.com/articles/life/dispatches/2012/01/
making_sense_of_muti_and_traditional_healing_culture_in_south_africa_.html.

Guelich, R.A., 1991, 'Spiritual warfare: Jesus, Paul and Peretti', The Journal of the Society for Pentecostal Studies 2(1), 33-64. https://doi.org/10.1163/15700 Society for
7491X00033

Harvey, D., 1990, The condition of postmodernity, Backwell, Cambridge.

Heyns, J.A., 1978, Dogmatiek, NG Kerkboekhandel, Pretoria.

Hickey, M., 2000, Breaking generational curses: Overcoming the legacy of sin in your family, Harrison House, Shippensburg, PA. 
Hiebert, P.G., 1982, 'The flaw of the excluded middle', Missiology: An International Review 10(1), 35-47. https://doi.org/10.1177/009182968201000103

Hinson, E.G., 1992, 'Historical and theological perspectives on Satan', Review and Expositor 89(4), 472. https://doi.org/10.1177/003463739208900403

Janse van Rensburg, J., 1999, The occult debate, Lux Verbi.BM., Cape Town.

Janse van Rensburg, J., 2010, 'A qualitative investigation into the so-called ministry of deliverance', In die Skriflig 44(3\&4), 679-697. https://doi.org/10.4102/ids. v44i3/4.16

Jones, P., 1997, Spirit wars: Pagan revival in Christian America, Wine Press Publishing Mukilteo, WA.

Jones, P., 2007, 'Paganism, the step-child of secularism', paper presented at the International Conference of World Reformed Fellowship, Utrecht, 6-9th October.

Jordaan, G.J.C., Janse van Rensburg, J. \& Breed, D.G., 2011, 'Hermeneutiese vertrekpunte vir gereformeerde eksegese', In die Skriflig 45(2\&3), 225-258. https://doi.org/10.4102/ids.v45i2/3.14

Joubert, S., 1997, "n Kykie na wat die Nuwe Testament oor engele sê', in S. Joubert \& J.G. van der Watt (eds.), Hy sal sy engel voor jou uitstuur: 'n Ontdekkingstog deur die Bybel, op soek na engele, pp. 35-44, CUM, Vereeniging.

Kathide, A.G., 2007, Hidden powers: Spirits in the first-century Jewish world, Luke-Acts and in the African context: An analysis, Acad-SA, Kempton Park.

Kato, B.H., 1975, What the Bible teaches: The spirits, Africa Christian, Achimota, Ghana.

Kirkpatrick, J., 2007, 'Bestaan die duiwel?', Teo.co.za.nuusbrief, p. 19

Koch, K.E., 1986, Occult ABC. Exposing occult practices and ideologies, Kregel, Grand Rapids, MI.

Kraft, C.H., 1995, 'Christian animism or God-given authority?' in E. Rommen (ed.) Spiritual power and missions, pp. 70-90, Carey, Pasadena, CA.

Leahy, F.S., 1990, Satan cast out: A study in biblical demonology, The Banner of Truth Trust, Carlise.

Lewis, C.S., 1942, The screwtape letters, MacMillan, London.

Lovelace, R., 1976, 'The occult revival in historical perspective', in J.W. Montgomery (ed.), Demon possession. A Medical, Historical and Theological Symposium pp. 65-90, Bethany Fellowship, Minneapolis, MN, paper presented at the University of Notre Dame under the auspices of the Christian Medical Association, 8-11th January, 1975.

Manala, M.J., 2004, 'Witchcraft and its impact on black African Christians: A lacuna in the ministry of the HervormdeKerk in Suidelike Afrika', Hervormde Teologiese Studies 60(4), 1491-1511. https://doi.org/10.4102/hts.v60i4.635

Makashinyi, I., 2019, The truth behind generational curses, viewed 19 April 2019, from https://africa.thegospelcoalition.org/article/truth-behind-generational-curses/.

Mbewe, C., 2013, The African import of charismatic chaos, viewed 19 April 2019, from https://www.youtube.com/watch?v=icil6qfd70s.

Mbiti, J., 1975, Introduction to African religion, Heinemann, Oxford.

Moyo, P.H., 1994, 'Reformed theology and the excluded middle: A reformed biblical theology of the demonic and exorcism', M.A. dissertation, Calvin Theology Seminary, Grand Rapids, MI.

Noll, S.F., 1998, Angels of light, powers of darkness: Thinking biblically about angels, Satan and principles, Wipf \& Stock, Eugene, OR.

Nugent, C., 1989, Mask of Satan: The demonic in history, Christian Classics, London.

Nyirongo, L., 1997, The gods of Africa or the God of the Bible? The snares of African traditional religion in biblical perspective, IRS, Potchefstroom. (Series F2, no 7).

Oesterley, W.O.E., 1906, 'Demon, demoniacal possession, demoniacs', in J. Hastings (ed.), A dictionary of Christ and the gospels: Aaron-Zion, p. 442, Charles Scribner's Sons, Edinburgh
Onyinah, O., 2004, 'Contemporary "witch demonology" in Africa', International Review of Mission 93, 330-345. https://doi.org/10.1111/j.1758-6631.2004. tb00463.x

Ouweneel, W., 1978, Het domein van de slang, Buiten \& Schipperheijn, Amsterdam.

Quayesi-Amakye, J., 2015, 'This nonsense must stop! Pentecostal negotiation of evil', Australasian Pentecostal Studies, viewed 20 April 2019, from https://www. researchgate.net/publication/304782525.

Quayesi-Amakye, J., 2016, 'The problematic of exorcism and spiritual warfare: A dialogue with Apostle Dr Opoku Onyinah', Journal of the European Pentecosta Theological Association, viewed 10 April 2019, from https://doi.org/10.1080/181 24461.2016.1258252

Peretti, F.E., 1986, This present darkness, Crossway Books, Wheaton.

Peretti, F.E., 1989, Piercing the darkness, Crossway Books, Wheaton.

Rath, N., 1999-2003, 'Enlightenment', in G.W. Bromiley \& E. Fahlbusch (eds), The encyclopaedia of Christianity, vol. 2, p. 96, Eerdmans, Grand Rapids, MI.

Sproul, R.C., 2011, Unseen realities: Heaven, hell, angels, and demons, Christian Focus Publications, Tain.

Taylor, J., 2012, How should we think about spiritual warfare?, viewed 15 April 2019 from https://www.thegospelcoalition.org/blogs/justin-taylor/how-should-wethink-about-spiritual-warfare/.

Theron, J.P.J., 2001, 'Die ontwikkeling van 'n groeiende bevrydingsbediening: ' $n$ literatuuroorsig veral met verwysing na invloedryke persone en kerklike tradisies', Acta Theologica 21(1), 180-197. https://doi.org/10.4314/actat.v21i1. 5485

Turaki, Y., 1999, Christianity and African gods: A method in theology, IRS, Potchefstroom. (Series F2, 75)

Unger, M.F. 1991, What demons can do to Saints, Moody, Chicago.

Unger, M.F. 1994, Biblical Demonology: A study of spiritual forces at work today, Kregel, Grand Rapids.

Van Aarde, A.G., 1987, 'Demonoly in New Testament times', in P.G.R. de Villiers (ed.) Like a roaring lion: Essays on the Bible, the church and demonic powers, pp. 22-37, UNISA, Pretoria.

Van der Meer, E., 2008, 'The strategic level spiritual warfare theology of C. Peter Wagner and its implications for Christian mission in Malawi', PhD dissertation, University of South Africa, Pretoria.

Vanhoozer, K.J., 1998, The Bible, the reader, and the morality of literary knowledge. Is there a meaning in this text? Zondervan, Grand Rapids, MI.

Vanhoozer, K.J., 2005, The drama of doctrine: A canonical linguistic approach to Christian theology, Westminster John Knox, Louisville, KY.

Van Wyk, I.W.C., 2004, 'African witchcraft in theological perspective', Hervormde Teologiese Studies 60(4), 1201-1228.

Veenstra, S., 2003, Healing ministry among the Zulu speaking people troubled by evil spirits: A missiological study, unpublished document.

Vergeer, W.C., 2002, 'Okkultiese binding en bevryding: 'n Nuwe-Testamentiese perspektief', In die Skriflig 36(3), 369-395. https://doi.org/10.4102/ids. v36i3.514

Viljoen, F.P. \& Floor, L., 2006, 'Goeie en slegte engele: 'n perspektief uit die Bybel', In die Skriflig 40(1), 35-56. https://doi.org/10.4102/ids.v40i1.332

Wagner, C.P., 1993, Churches that pray, Regal, Ventura, CA.

Wagner, C.P., 1996, Confronting the powers: How the New Testament church experienced the power of strategic-level spiritual warfare, Regal, Ventura, CA

Watkins, J.N., 1990, Demons, possession or obsession? viewed 15 April 2019, from http://www.jameswatkins.com/articles-2/heavy/demons/. 